\title{
Influence of Dopamine on Rat Uterine Motility in vitro
}

\author{
A. CZERSKI, W. ZAWADZKI, M. ZAWADZKI, Z. CZERSKA
}

Department of Animal Physiology, Agricultural University, Norwida 31, Wrocław, Poland

Received September20, 2004

Accepted March 3, 2005

\begin{abstract}
Czerski A., W. Zawadzki, M. Zawadzki, Z. Czerska: Influence of Dopamine on Rat Uterine Motility in vitro. Acta Vet. Brno 2005, 74: 9-15.

The effect of dopamine on spontaneous rhythmic contractions of isolated rat uterine muscles was examined. The experiments were carried out on 25 female Buffalo rats aged between 4-6 months. Myometrial tissue (1.5- $2 \mathrm{~cm}$ long) was set up in 4 isolated organ baths $(20 \mathrm{ml})$ at $37^{\circ} \mathrm{C}$. After recording the pattern of myometrial tissue spontaneous motility: dopamine, domperidone, metoclopramide, clozapine, bromocriptine, prazosine, propranolol were added into the organ baths. The dose of the formulae was fixed in preliminary experiments. Myometrial strips incubated in the isolated organ baths had spontaneous motility for about 8 to $12 \mathrm{~h}$. The spontaneous motility frequency amounted to about $1.15 \pm 0.38$ contractions per min. The contraction strength was on average $2.8 \pm 0.45$ grams.

The addition of dopamine into the incubation bath organ at a concentration of $1.3 \cdot 10^{-4}$ $\mathrm{mol} / \mathrm{L}$ significantly reduced the strength $(63 \%, p<0.001$, to the value of $1.04 \pm 0.18$ grams $)$ and frequency $(27 \%, p<0.01$, to the value $0.84 \pm 0.21$ per minute) of spontaneous rhythmic contractions. The addition of dopamine at a concentration of $2.6 \cdot 10^{-4} \mathrm{~mol} / \mathrm{L}$ totally inhibited the uterine spontaneous contractions. The attempt at blocking dopaminergic receptors with metoclopramide, domperidone and clozapine did not prevent uterus atony caused by the addition of dopamine. Uterus contractility was not affected by activating dopaminergic receptors with bromocriptine $\mathrm{D}_{1}$ and $\mathrm{D}_{2}$ receptors agonist, and the obtained recording exhibited no statistically significant differences in comparison to the initial recording. Simultaneous blocking of $\alpha_{1}$ adrenergic receptors with prazosine and $\beta$ adrenergic receptors with propranolol counteracted uterus atony after the addition of dopamine to the incubation bath organ.

The results indicated a blocking influence of dopamine on uterus contractility in rats in vitro related to a concentration of dopamine and caused by activating adrenergic receptors with dopamine.
\end{abstract}

Dopamine receptors, bath, incubation, myometrium, contractility, atony, receptor agonist, in vitro, rat

Dopamine participates in regulating many biological processes. To a large extent it influences the central nervous system and regulates movement control, muscle tension as well as the secretion of prolactin and sex hormones. Disorders connected with dopamine biosynthesis in the central nervous system cause many diseases e.g. Parkinson's disease, chorea. Dopaminergic receptors are also found outside the nervous system e.g. pituitary gland, parathyroid glands, thyroid gland, pancreas, digestive tract and ductus deferens. Dopamine works not only through dopaminergic receptors but also through the adrenergic ones (Anuras 1981; Hovendal et al. 1982; Węgrzyn et al. 1988; Węgrzyn et al. 1994; $\mathrm{Zięb} \mathrm{a} \mathrm{et} \mathrm{al.} \mathrm{1991).} \mathrm{Dopamine} \mathrm{influences} \mathrm{organs} \mathrm{in} \mathrm{many} \mathrm{ways,} \mathrm{which} \mathrm{depends} \mathrm{on} \mathrm{the} \mathrm{organ}$ being examined and an animal's species. Dopamine blocks the motility of both human and canine stomach as well as that of rumen, abomasal and small intestine in ruminants (B u e no et al. 1983; Cebrat et al. 1989; De Carle and Cristensen 1976; Węgrzyn et al. 1988; Węgrzyn et al. 1994; Zięba et al. 1991). On the other hand, it activates the motility of human duodenum and colon (Anuras 1981; Lanfranchi et al. 1979; Marzio et al. 1986).

Dopamine has also an activating effect on myometrium. According to Zięba (Zięba and Dejneka 1996) dopamine administered intravenously to sheep sensitized by stilboestrol causes an increase in uterus myoelectrical activity. The research carried out by Arkinstall and Jones

Address for correspondence:

A. Czerski

Department of Animal Physiology

Agricultural University, Norwida 31

50-375 Wrocław, Poland

Phone: +048 0713205162

E-mail: Albert-Czerski@wp-pl

http://www.vfu.cz/acta-vet/actavet.htm 
(1985) also confirms the presence of this catecholamine in the uterine smooth muscles of humans, rabbit, sheep, guinea pig and rat. According to Moustafa, activating the dopaminergic receptor with bromocriptine (a selective $\mathrm{D}_{2}$-agonist and weak partial agonist at the $\mathrm{D}_{1}$ receptor) in both in vitro and in vivo experiments causes an increase in myometrial contraction in the early stage of rat pregnancy (Moustafa et al. 1999; Clark and White 1987).

Because to our knowledge no data are available on myometrial contraction under the effect of dopamine, our research was aimed at the study of the influence of dopamine on this phenomenon in rats under in vitro conditions.

\section{Materials and Methods}

The experiments were carried out on 25 Buffalo clinically healthy female rats aged 4-6 months at the weight of 150-170 g. Rats were housed collectively (5-6 rats in the metal cages) at a temperature of approximately $22^{\circ} \mathrm{C}$ with a daylight cycle and fed ad libitum the LSM balanced rodent-diet (firm Agropol S.J.). The experiments were carried out with the consent of the Ethical Committee (No. 60/04). The animals were subjected to halothane general anaesthesia and after death their uterus strips $1.5-2 \mathrm{~cm}$ long were taken for examination. The strips were placed in 4 automatic bath organs of $20 \mathrm{ml}$ capacity in accordance with the procedure of Alvarez et al. (1988) and Daly et al. (1981). The KrebsHenseleit buffer $\left(\mathrm{NaCl}-118 \mathrm{mM} ; \mathrm{KCl}-4.7 \mathrm{mM} ; \mathrm{CaCl}_{2}-2.5 \mathrm{mM} ; \mathrm{MgSO}_{4}-1.6 \mathrm{mM} ; \mathrm{NaHCO}_{3}-24.3 \mathrm{mM}_{2} \mathrm{KH}_{2} \mathrm{PO}_{4}\right.$ $-1.18 \mathrm{mM}$; glucose $5.6 \mathrm{mM}$ ) (Coruzzi et al. 1988) was used as an incubation environment. The incubation of strips was conducted at the temperature of $37^{\circ} \mathrm{C}$, loaded with $1 \mathrm{~g}$ and the oxygen and carbon dioxide gas mixture $\left(95 \% \mathrm{O}_{2}\right.$ and 5\% $\mathrm{CO}_{2}$ ) was added so that its $\mathrm{pH}$ remained within 7.3-7.5. Myometrial contractions were recorded by isometric transducers (Letica Scientific Instruments) connected to BridgeAmp amplifiers (ADInstruments, Australia) with 4 channel data acquisition system (PowerLab/400, ADInstruments) connected to a Macintosh computer. After a 30min recording of spontaneous myometrial contraction activity the following were added into the bath organs: dopamine $-\mathrm{D}_{1}$ and $\mathrm{D}_{2}$ receptors agonist (Dopamine hydrochloride SIGMA) at a concentration of $2.6 \mathrm{~mol} / \mathrm{L} \cdot 10^{-4}$, domperidone $\mathrm{D}_{2}$ receptor antagonist (Domperidone SIGMA) at a concentration of $0.67 \cdot 10^{-3}$ (Laduron and Leysen 1979, Lazareno and Nahorski 1982), metoclopramide $-\mathrm{D}_{2}$ receptor antagonist (Metoclopramide hydrochloride SIGMA) at a concentration of $0.83 \cdot 10^{-3}$ (Pero 1999), clozapine (Clozapine SIGMA) at a concentration of $0.76 \cdot 10^{-3} \mathrm{~mol} / \mathrm{L}$, bromocriptine $-\mathrm{D}_{2}$ and $\mathrm{D}_{1}$ receptor agonist (Bromergon-Lek Polska) at a concentration of $0.94 \cdot 10^{-3} \mathrm{~mol} / \mathrm{L}$, prazosine$\alpha_{1}$-adrenergic receptors antagonist (Prazosin HCL, USP grade - RBI) at a concentration of $0.59 \cdot 10^{-4} \mathrm{~mol} / \mathrm{L}$, propranolol- $\beta_{1}$ and $\beta_{2}$ adrenergic receptors antagonist (Propranolol Polfa) at a concentration of $0.8 \cdot 10^{-4} \mathrm{~mol} / \mathrm{L}$.

In order to determine the effective dose the substances were added to the incubation bath ranging from the lowest dilution to the highest one in the dose concentration system (that is without rinsing the bath between the subsequent additions of the doses to the bath). The lowest substance concentration that yielded an evident result on the recording was accepted as the experimental dose and was confirmed in a number of following experiments.

The frequency of contractions per min and the strength of contractions given in grams were taken into consideration while summarizing the obtained results.

The results were summarized in the Microsoft Excel 2000 and analyzed statistically using the Student's $t$-test and the analysis of variance (ANOVA).

\section{Results}

The uterus strips placed in the automatic bath organ exhibited periodical contractility with a frequency of $1.15 \pm 0.38$ contraction per min. The strength of the single contraction was on average $2.8 \pm 0.45 \mathrm{~g}$.

The addition of dopamine to the incubation bath organ at a concentration of $0.26 \cdot 10^{-4}$ $\mathrm{mol} / \mathrm{L}$ per bath organ did not cause any statistical differences in uterus motility, but at a concentration of $1.3 \cdot 10^{-4} \mathrm{~mol} / \mathrm{L}$ caused a decrease in both the frequency $(27 \%(p<0.01)$, to the value $0.84 \pm 0.21$ per minute) and strength $(63 \%(p<0.001)$ to $1.04 \pm 0.18)$ (hypotonia), and a total lack in spontaneous contractility at a concentration of 2.6 $10^{-4} \mathrm{~mol} / \mathrm{L}$ (atony) (Figs 1, 2, 3).

The attempt at blocking $\mathrm{D}_{1}$ dopaminergic receptors with metoclopramide, domperidone and clozapine did not prevent from uterus atony caused by the addition of dopamine (Figs $4,5,6)$. Uterus contractility was not affected by activating dopaminergic receptors with bromocriptine and the obtained recording exhibited no statistically significant differences in comparison to the initial recording. Simultaneous blocking of $\beta_{1}$ adrenergic receptors with prazosine, and $\beta$ adrenergic receptors with propranolol counteracted uterus atony caused by the addition of dopamine to the incubation bath (Fig. 7). 


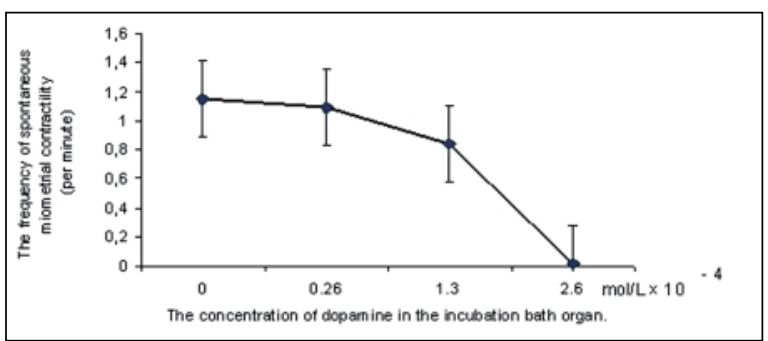

Fig. 1. The influence of dopamine concentration on the frequency of spontaneous uterine contractility in rats in vitro. An evident decrease in frequency and an increase in dopamine concentration.

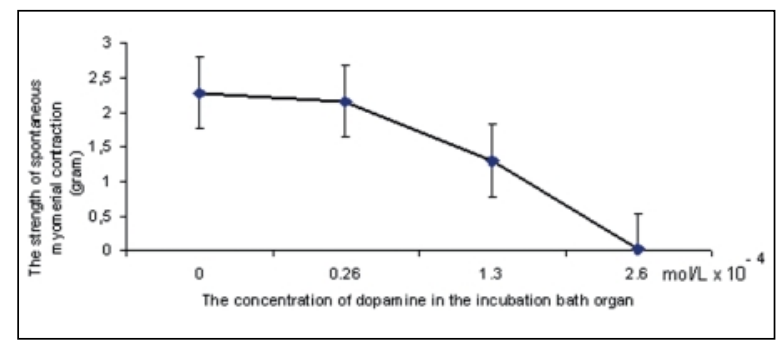

Fig. 2. The influence of dopamine concentration on the strength of spontaneous uterine contractility in rats in vitro. An evident decrease in strength and an increase in dopamine concentration.

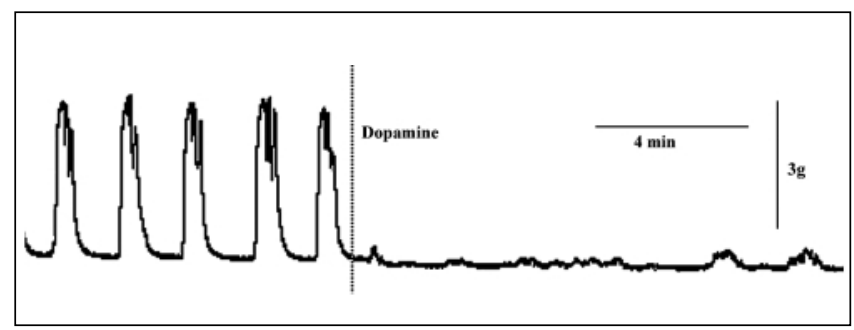

Fig. 3. The recording of uterus motility before and after the addition of dopamine at a concentration of $2,6 \mathrm{~mol} / \mathrm{L} \cdot 10^{-4}$. An evident decrease in motility of an isolated strip (atony). The addition time of dopamine was marked by the dotted line.

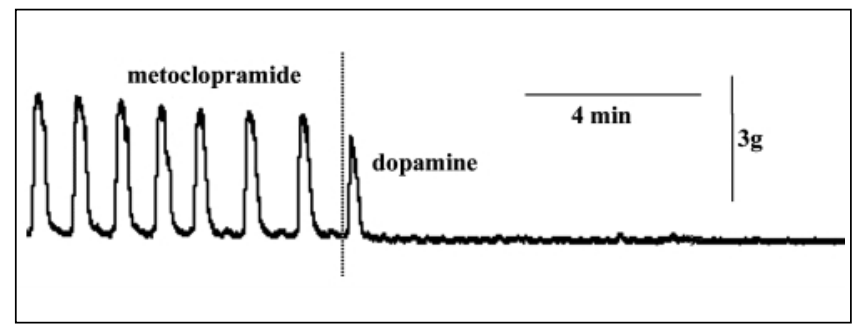

Fig. 4. The recording of myometrial contractility after blocking the $\mathrm{D}_{2-}$ dopaminergic receptor with metoclopramide and the addition of dopamine. An evident lack in the influence of metoclopramide on the blocking effect of dopamine on uterus contractility. 


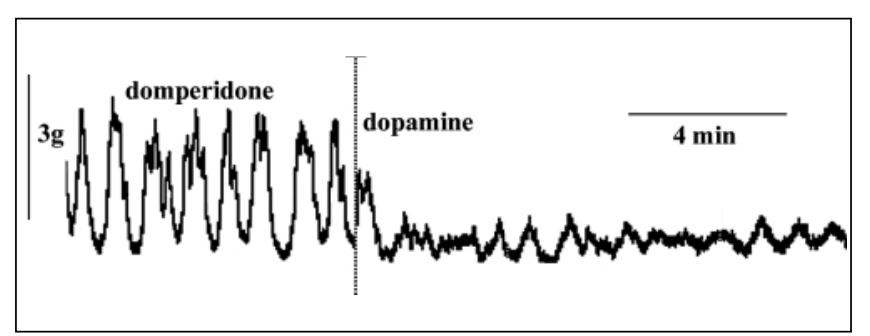

Fig. 5. The recording of myometrial contractility after blocking the $\mathrm{D}_{2}$-dopaminergic receptor with domperidone and the addition of dopamine. An evident lack in the influence of domperidone on the blocking effect of dopamine on uterus contractility.

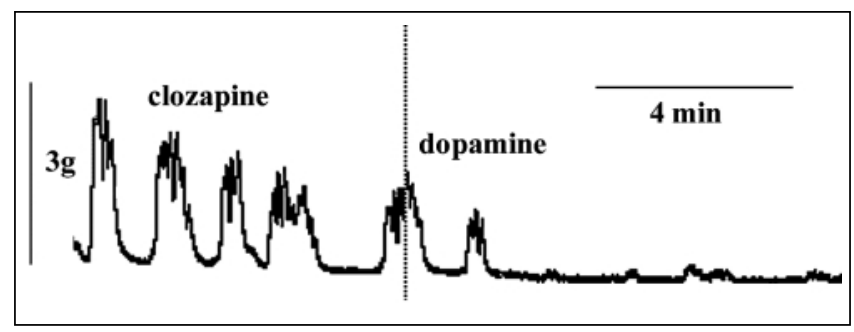

Fig. 6. The recording of myometrial contractility after blocking the $\mathrm{D}_{1}$ and $\mathrm{D}_{2-}$ dopaminergic receptor with clozapine and the addition of dopamine. An evident lack in the influence of clozapine on the blocking effect of dopamine on uterus contractility.

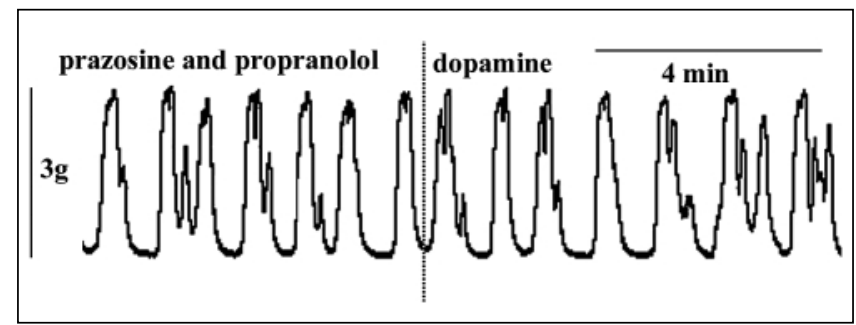

Fig. 7. The recording of myometrial contractility after blocking adrenergic receptors with prazosine and propranolol and the addition of dopamine. An evident lack in the influence of dopamine on spontaneous contractility after blocking adrenergic receptors.

\section{Discussion}

Administration of dopamine to animals causes different, often opposing reactions dependent both on the examined organs and the species. Dopamine influences organs not only through dopaminergic receptors but also through the adrenergic ones. According to Węgrzyn et al. (1994) dopamine blocks the motility of abomasum through $\mathrm{D}_{2}$ dopaminergic and $\alpha$-adrenergic receptors. Dopamine has also a blocking effect on the motility of ileum through $\alpha$-adrenergic receptors ( $\mathrm{Zięb}$ b et al. 1991).

As far as uterine smooth muscles are concerned the presence of cell membrane receptors including the dopaminergic ones is strongly related to hormones, mainly oestrogens. Other authors also emphasize the importance of oestrogens in changing the concentration of different cell membrane receptors (Ayad et al. 1989; Gilbert et al. 1992; Massmann et 
al. 1991; Sheldrick and Flint 1985). Arkinstall and Jones (1985) indicated the presence of endogenous dopamine in uterus muscles, and F or s berg et al. (1987) exhibited the influence of dopamine on rat uterus cervix contractility. According to Zięba and Dejneka (1996) dopamine stimulates uterine myoelectrical activity in sheep sensitized by stilboestrol and its stimulating effect is not carried out by dopaminergic receptors. An increase in uterine pressure is caused by administration of dopamine to pregnant sheep (F is hburne et al. 1980). A similar increase in uterine contractility is noticed in women after the infusion of dopamine (Urban et al. 1982). An increase in uterus contractility is also noticed after the administration of bromocriptine (the agonist of dopaminergic receptors) to rats in early pregnancy (for the period of 11 days beginning from the 9th day) (Moustafa et al. 1999).

Dopamine stimulates uterine contractility in rabbits, rats and women in early pregnancy (Lal and Sharma 1983; Sizov 1992; Urban et al. 1982; Ekesbo et al. 1991). It blocks muscle relaxation effect caused by releasing relaxin during parturition (Sizov 1992). The stimulating effect of dopamine and bromocriptine on uterus contractility in vivo is related to the fact that they increase the level of vasopressin (vasopressin stimulates uterus contractility), and decrease the concentration of $\mathrm{PGI}_{2}$ ( $\mathrm{PGI}_{2}$ blocks uterus contractility) in the uterus (Robinson et al. 1982; Hauksson et al. 1988; Ageel et al. 1985).

The uterine strips placed in the automatic bath organ exhibited periodical contractility as confirmed by earlier experiments carried out by Czerski et al. (2004) and other authors (Estan et al. 1988; Parija et al. 2001). The addition of dopamine to the incubation bath organ at a concentration of $2.6 \cdot 10^{-4} \mathrm{~mol} / \mathrm{L}$ resulted in atony of the isolated strip. Similarly, Estan et al. (1988) obtained atony of the isolated strips in rats after the addition of dopamine at a concentration of $10^{-7}$ to $10^{-4} \mathrm{~mol} / \mathrm{L}$. The decrease in uterine contractility was in direct proportion to the concentration of dopamine in the bath organ. On the contrary, Lechner et al. (1996) obtained an increase in uterus activity in vitro after the addition of dopamine at a concentration of $10^{-6} \mathrm{~mol} / \mathrm{L}$. Blocking dopaminergic receptors with metoclopramide, domperidone and clozapine did not prevent from atony after the addition of dopamine. The obtained results indicated that the blocking effect of dopamine on uterus contractility was not carried out through dopaminergic receptors (Estan et al. 1988).

According to Lechner et al. (2000) the addition of metoclopramide blocks spontaneous contractility of the isolated uterus strips removed from women during a caesarean section. The blocking effect of metoclopramide was not observed in our research. A different hormonal profile of a female (pregnancy) as well as a different species can change the influence of metoclopramide on spontaneous contractility. Dopamine can also influence organs through adrenergic receptors (e.g. Węgrzyn et al. 1994; Zię ba et al. 1991).

Stimulating adrenergic receptors with selective agonists, except for $\alpha_{2}$-adrenergic ones which has an activating effect, blocks uterus contractility in rats in vitro (Czerski et al. 2004). In other animal species, for example in sheep, it can be different. Blocking adrenergic receptors with prazosine (the antagonist of $\alpha_{1}$-adrenergic receptors) and with propranolol (the antagonist of both subtypes of $\beta$-adrenergic receptors) prevented from atony of uterus muscles after the addition of dopamine. Dopamine could cause uterine atony through stimulating adrenergic receptors. Similarly, Estan et al. (1988) also obtained a blocking effect of dopamine on uterus contractility carried out through $\beta$ adrenergic receptors. However, blocking $\beta$-adrenergic receptors with propranolol or blocking $\alpha_{1}$-adrenergic ones with prazosine did not counteract uterine atony after the addition of dopamine. It was simultaneous blocking of both $\beta$-adrenergic and $\alpha_{1}$ adrenergic receptors that counteracted the influence of dopamine on spontaneous contractility. 


\section{Účinek dopaminu na motilitu dělohy potkanů in vitro}

Byl zkoumán účinek dopaminu na spontánní rytmické kontrakce izolovaných svalových buněk dělohy potkanů. Experimenty byly provedeny na 25 samicích potkanů Buffalo, ve věku 4-6 měsíců. Tkáň myometria (1,5-2 cm dlouhý proužek) byla vložena do 4 izolovaných orgánových lázní $(20 \mathrm{ml})$ o $37{ }^{\circ} \mathrm{C}$. Po zaznamenání rytmu spontánní motility tkáně myometria byly do orgánových lázní aplikovány: dopamin, domperidon, metoclopramid, clozapin, bromocriptin, prazosin a propranolol. Dávka látek byla stanovena $\mathrm{v}$ předběžných pokusech. Proužky myometria inkubované v izolovaných orgánových lázních vykazovaly spontánní motilitu po dobu cca 8 až 12 hodin. Frekvence spontánní motility se pohybovala kolem 1,15 $\pm 0,38$ kontrakcí za minutu. Síla kontrakce byla průměrně 2,8 $\pm 0,45$ gramů. Přidání dopaminu do orgánové inkubační lázně v koncentraci $1,3 \cdot 10^{-4} \mathrm{~mol} \cdot \mathrm{l}^{-1}$ signifikantně snížilo sílu (63\%, $p<0,001$, na hodnotu 1,04 $\pm 0,18$ gramů) a frekvenci $(27 \%, p<0,01$, na hodnotu $0,84 \pm 0,21$ za minutu) spontánních rytmických kontrakcí. Přidání dopaminu v koncentraci $2,6 \cdot 10^{-4} \mathrm{~mol} \cdot \mathrm{l}^{-1}$ zcela inhibovalo spontánní rytmické kontrakce dělohy. Pokus o blokování dopaminergních receptorů metoclopramidem, domperidonem a clozapinem nezabránilo atonii dělohy způsobené přidáním dopaminu. Kontraktilita dělohy nebyla ovlivněna aktivací dopaminergních receptorů bromokriptinem, agonistou $\mathrm{D}_{1}$ a $\mathrm{D}_{2}$ receptorů, a získané záznamy neprokázaly žádné statisticky významné rozdíly ve srovnání s výchozími. Simultánní blokování $\alpha_{1}$ adrenergních receptorů prazosinem a $\beta$ adrenergních receptorů propranololem působilo proti atonii dělohy po přidání dopaminu do inkubační orgánové lázně.

Výsledky ukazují blokující účinek dopaminu na kontraktilitu dělohy potkanů in vitro závislý na koncentraci dopaminu a způsobený aktivací adrenergních receptorů dopaminem.

\section{References}

AGEEL, AM, EL-TAHIR, KE, ABU-JAYYAB, AR 1985: Effect of bromocriptine on prostacyclin release and cyclic nucleotides on rat aortic and uterine tissues. Prostaglandins 30: 369-381

ALVAREZ, FJ, VALASCO, A, PALOMARES, JL 1988: Blockada of muscarinic, histamine $\mathrm{H}_{1}$ and histamine $\mathrm{H}_{2}$ receptors by antidepressants. Pharmacology 15: 177-184

ANURAS, S 1981: Effect of dopamine on opossum smooth muscle. Gastroenterology 80: 51-57

ARKINSTALL, SJ, JONES, CT 1985: Regional changes in catecholamine content of the pregnant uterus. J Reprod Fert 73: 547-557

AYAD, VJ, WATHES, DC, MCGOFF, SA, GILBERT, CL 1989: Comparison of the actions of oxytocin and Argvasopressin on the EMG activity on the reproductive tract of oestrogen-treated anestrus ewes. J Reprod Fert 4: 26-37

BUENO, L, SORRAING, JM, FIRZAMONTI, J 1983: Influence of dopamine on rumino-reticularmotility and rumination in sheep. J Vet Pharmacol Therap 6: 93-99

CEBRAT, E, WEGRZYN, T, ZIĘBA, D, LEROCH, Z 1989: The Influence of dopamine on small intestine motility in the sheep. Pol Arch Wet 29: 71-79

CLARK, D, WHITE, FJ 1987: D1 dopamine receptor the search for a function: a critical evaluation of the $\mathrm{D}_{1} / \mathrm{D}_{2}$ dopamine receptor classification and its functional implications. Synapse 1: 347-388

CORUZZI, G, POLI, E, MONTANARI, C, BERTACCINI, G 1988: Pharmacological characterization of mare uterus motility with special reference to calcium antagonists and beta-2-adrenergic stimulants. Gen Pharmacy 20: $513-518$

CZERSKI, A, ZAWADZKI, W, WINCEWICZ, E, W, ODARCZYK, M, CWYNAR, P 2004: The influence of alpha-adrenergic receptors on uterus motility in the rat in in vitro research. Med Vet 60: 736-738

CZERSKI, A, ZAWADZKI, W, WINCEWICZ, E, ZAWADZKI, M, JANECZEK, M, W, ODARCZYK, M 2004: The Influence of $\beta$-adrenergic receptors on uterus motility in the rat in in vitro research. Acta Sci Pol Med Vet 3(1): $9-18$

DALY, M, HUMPHRAY, JM, STABLES, R, 1981: Some ,in vitro“ and ,in vivo“ actions of the new histamine $\mathrm{H} 2$ receptor antagonist ranitidine. Brit J Pharmacol 72: 49-54

DE CARLE, DJ, CHRISTENSEN, J 1976: A dopamine receptor in esophageal smooth muscle of opossum. Gastroenterology 70: 216-225

EKESBO, R, ALM, P, EKSTROM, P, LUNDBERG, LM, AKERLUND, M 1991: Innervation of the human uterine artery and contractile response to neuropeptides. Gynecol Obstet Invest 31: 30-36 
ESTAN, L, MARTINEZ-MIR, I, RUBIO, E, MORALES-OLIVAS, FJ 1988: Relaxant effect of dopamine on the isolated rat uterus. N-S Arch Pharmacol 338: 484-488

FISHBURNE, JI, MEIS, PJ, URBAN, RB, GREISS, FC, WHEELER, AS, JAMES, FM, SWAIN, MF, Rhyne, AL 1980: Vascular and uterine responses to dobutamine and dopamine in gravid ewe. Am J Obstet Gynecol 137: 944-952

FORSBERG, G, ENEROTH, P, SONDERSTEN, P 1987: Naloxone stimulates sexual behaviour in lactating rats. J Endocrinol 113: 412-423

GILBERT, CL, CRIPPS, PJ, WATHES, DC 1992: Effect of oxytocin on the pattern of electromyographic activity in the oviduct and uterus of the ewe around oestrus. Reprod Fert Develop 4: 193-203

HAUKSSON, A, AKERLUND, M, MELIN, P 1988: Uterine blood flow and myometrial activity at menstruation, and the action of vasopressin and a synthetic antagonist. Brit J Obstet Gynaecol 95: 898-904

HOVENDAL, CP, BECH, K, GOTTRUP, F, ANDERSON, D 1982: Effect of dopamine on pentagastrinstimulated gastric acid secretion and mucosal blood flow in dogs with gastric fistula. Scand J Gastroenterol 17: 97-106

LADURON, PM, LEYSEN, JE 1976: Domperidone, a specific in vitro dopamine antagonist, devoid of in vivo central dopaminergic activity. Biochem Pharmacol 28: 2161-2165

LAL, R, SHARMA, PL 1983: Preliminary study on the mechanisms of dopamine action on rabbit myometrium. Indian J Med Res 77: 265-270

LANFRANCHI, DA, MARZIO, L, CORRTINI, C, MORENO, E 1979: Motor effect of dopamine on human sigmoid colon. Am J Dig Dis 23: 257-264

LAZARENO, S, NAHORSKI, SR 1982: Selective labelling of dopamine $\left(\mathrm{D}_{2}\right)$ receptors in rat striatum by $[3 \mathrm{H}]$ domperidone but not by [3H] spiperone. Eur J Pharmacol 81: 273-285

LECHNER, W, SOLDER, E, BERGANT, A 1996: Effect of dopamine on uterine contraction. Zentralbl Gynakol 118: $406-408$

LECHNER, W, BERGANT, A 2000: Effect of the dopamine antagonist metoclopramide on uterine contraction. Z Geburtshilfe Neonatol 204: 114-116

MARZIO, L, NERI, M, DI GIAMMARCE, AM 1986: Dopamine-induced migrating myoelectrical complex-like activity in human duodenum. Dig Dis Sci 31: 349-357

MASSMANN, GM, FIGUEROA, JP, NATHANIELSZ, PW 1991: Futher characterization of electromyographic activity of the myometrium and mesometrium in nonpregnant sheep under estrogen supplementation. Biol Reprod 45: 605-610

MOUSTAFA, AM, EL-SAYED, EM, BADARY, OA, MANSOUR, AM, HAMADA, FMA 1999: Effect of bromocriptine on uterine contractility in near-term pregnant rats. Pharmacol Res 39: 89-95

PARIJA, SC, RAVIPRAKASH, V, TELANG, AG, VARSHNEY, VP, MISHRA SK 2001:Influence of hypothyroid state on $\mathrm{Ca}^{2+}$ influx and sensitivity of rat uterus to nifedipine and diltiazem. Eur J Pharmacol 421: 207-213

PERO, RW 1999: Newly discovered anti-inflammatory properties of the benzamides and nicotinamides. Mol Cell Biochem 193: 119-125

ROBINSON, BG, CLIFTON-BLIGH, P, POSEN, S, MORRIS, BJ 1982: The effect of bromocriptine on circulating vasopressin. Clin Sci 63: $367-372$

SHELDRICK, EL, FLINT, APF 1985: Endocrine control of uterine oxytocin receptors in the ewe. J Endocrinol 106: $237-249$

SIZOV, PI 1992: Action of GABA-positive preparations on uterus-stimulating effects of activating neuromediators, prostaglandin F2 alpha and oxytocin. Biull Eksp Biol Med 113: 387-389

URBAN, J, RADWAN, J, LAUDANSKI, T, AKERLUND, M 1982: Dopamine influence on human uterine activity at term pregnancy. Brit J Obstet Gynaecol 98: 451-455

WEGGRYN, T, CEBRAT, E, LEROCH, Z, ZIĘBA, D, DĘBOWY, J 1988: Influence of dopamine on rumen motility in sheep. Sci. Lett (Wrocław Agric University) 46: 62-69

WĘGRZYN, T, CEBRAT, E, ZIĘBA, D, LEROCH, Z 1994: Influence of dopamine on the abomasum motility in sheep. Sci Lett (Wrocław Agric University) 53: 69-71

ZIĘBA, D, WĘGRZYN, T, CEBRAT, E, LEROCH, Z 1991: The influence of dopamine on ileum motility in the sheep. Pol Arch Vet 31: 109-114

ZIĘBA, D, DEJNEKA, J 1996: The Influence of dopamine on uterus myoelectrical activity in the sheep sensitized and not sensitized by stilboestrol. Sci Lett (Wrocław Agric University) 55: 68-75 